\title{
XX. Remarks on Mr. Drummond Hay's observations on the Gopher-wood of the received version of the scriptures
}

\section{Charles T. Beek Esq.}

To cite this article: Charles T. Beek Esq. (1833) XX. Remarks on Mr. Drummond Hay's observations on the Gopher-wood of the received version of the scriptures, Philosophical Magazine Series 3, 3:14, 103-104, DOI: 10.1080/14786443308648134

To link to this article: http://dx.doi.org/10.1080/14786443308648134

曲 Published online: 01 Jun 2009.

Submit your article to this journal $[\pi$

Џll Article views: 3

Q View related articles ¿ 
XX. Remarks on Mr. Drummond Hay's Observations on the Gopher-wood of the received Version of the Scriptures. By Charles T. Beek, Esq.

To the Editors of the Philosophical Magazine and Journal of Gentlemen, Science.

I $\mathrm{N}$ a paper which appears in your Magazine for June, headed "Notices of certain Plants of Marocco," Mr. Drummond Hay supports the opinion, that the Cedar was the wood of which Noah built the Ark, on the authority of the Chaldee Paraphrase, in which the word of the Hebrew text jפٍ (Gopher), Gen.vi. 14, is represented by the word קדרוֹ (Kadros), which is usually rendered cedrus.

I am not aware, however, that the Targum is of itself entitled to greater deference than the various authorities which exist in favour of other descriptions of wood. The whole of these authorities are cited in Dr. Rees's Cyclopædia, in the article "Ark."

But my object in addressing you is neither to dispute the claims of the Cedar, nor to advocate those of any other tree; but simply to show what is the literal meaning of the words

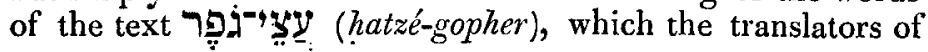
our authorized version have written Gopher-roood.

Now the interchange between the letters $\lambda$ and $J$ being common in the Hebrew and cognate languages, owing to their being letters of the same organ, and of nearly the same sound (see Lee's Hebrew Grammar, 2nd Edit. p. 35. Art. 78.), I consider the word גפר (Gopher) to be in fact identical with כָפר (Kopher), which occurs with it in the same verse, and of which the meaning is Pitch. Should it be objected that it is hardly likely that these letters are thus convertible in the same passage, another instance of the like interchange may be ad-

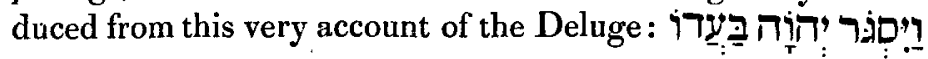
(Vayisgór yehơáh báhadó). 'And God shut up (the Ark) on

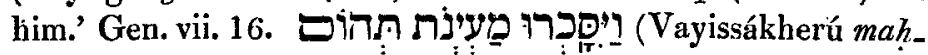
yenóth tehom). 'And the fountains of the deep-were shut up.' Gen. viii. 2.

Isaac Delgado, a learned Jew, who in 1789 published an English translation of the Pentateuch, in like manner consi-

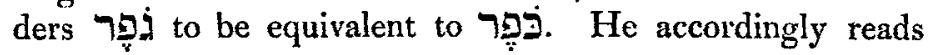


"pitched planks"; "ע. being, as he says, in the plural number, and signifying planks or boards. But in this latter respect he is clearly in error; since the primary and proper

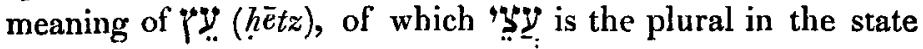
of construction, is Tree and not Plank. See Gen. i. 29. Deut. xxii. 6. and innumerable other texts.

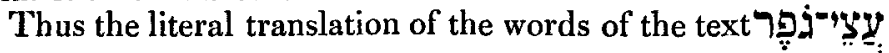
is "Trees of Pitch," or "Pitch Trees," meaning the wood of that description of tree from which pitch is obtained.

It remains to be ascertained what tree, the product of the country where the Ark was built, is most likely to have had this name applied to it by Moses; - on which I confess my incompetency to offer an opinion.

Another observation on Mr. Drummond Hay's paper I make with regret. It is with respect to his remarks on the manner in which Padre Felipe Scio has rendered these same words shittim), Exod. xxv. 10, in his Spanish Version of the Bible. I have no intention to advocate the worthy Padre's translation, but I feel persuaded that Mr. Drummond Hay would not have ridiculed him for his "utter ignorance" if he had not overlooked the fact, that this modern Spaniard has merely followed the ancient authority of the Vulgate; he having translated the "ligna lavigata" of that version by " maderas labradas," and the "ligna de setim" of the same by " maderas de setim." I am, Gentlemen,

Your most obedient Servant,

North Buildings, Finsbury Circus, $\quad$ Charles T. Beek. June $7,1833$.

XXI. Characters of some undescribed Genera and Species of Araneidæ. By JoHN Blackwall, Esq. F.L.S. \&c.*

Tribe, Tubitele, Latreille.

Genus, Savignia.

FYES six in number, unequal in size; four of them, which are disposed in a transverse row behind the anterior prominence of the cephalothorax, are separated by large intervals, the two intermediate ones being the smallest of the six, and immediately before each of the lateral eyes another is situated.

* Communicated by the Author. 